\title{
Tectonic control on the distribution of onshore mud volcanoes in parts of the Upper Benue Trough, northeastern Nigeria.
}

\author{
Ojochenemi K. Musa ${ }^{1 *}$, Ewa E. Kurowska ${ }^{2}$, Krzysztof Schoeneich ${ }^{3}$, \\ Solomon A. Alagbe ${ }^{1}$, Jeremiah Ayok ${ }^{1}$ \\ ${ }^{1}$ Department of Geology, Federal University, Lokoja, Adankolo Campus, P.M.B. 1154, Lokoja, Kogi \\ State, Nigeria \\ ${ }^{2}$ Department of Fundamental Geology, University of Silesia in Katowice, Poland \\ ${ }^{3}$ Department of Geology, Ahmadu Bello University, Zaria, Kaduna State, Nigeria \\ *Correspondence: kizi.musa@gmail.com;
}

Received: $22^{\text {th }}$ December, 2015

Accepted: $14^{\text {th }}$ April, 2016

\begin{abstract}
Onshore mud volcanoes are rare geological phenomena, which in Nigeria were reported for the first time few years ago in the Upper Benue Trough. In this study a detail geological mapping of the area of mud volcanoes occurrence was carried out, with the primary aim of defining their relationship, if any, to the structural geology there. The systematic field reconnaissance included field observations of the structural features, as well as analysis of the location and distribution of the onshore mud volcanoes, marking their locations on the topographic and geological maps, analysis of the aerial photographs and satellite images. The study area covered the central part of the Upper Benue Trough where the onshore mud volcanoes were found. The study area is the part of a sedimentary basin comprising Cretaceous clastic rocks that have been deformed intensively by a network of faults often embedded in the underlying Precambrian basement. This network of faults underwent a rejuvenation period from the Aptian to the Palaeocene. The most prominent tectonic structure in the study area is the NE - SW trending Kaltungo Fault Zone, however, there are other minor faults with $\mathrm{N}-\mathrm{S}$ and NW $-\mathrm{SE}$ trends. This study shows that the mud volcanoes found in the study area are usually located near or within fault zones, within the outcropping Upper Cretaceous Yolde Formation and Upper Bima Sandstone, both of which were deformed by the Kaltungo faults, as well as by other minor faults.

Worldwide, incidences of onshore mud volcano formation are usually attributed to areas of tectonic activity, rapid sedimentation or hydrocarbon occurrence. In this study, the interpretation of the field observations and mapping results, combined with information on the structural evolution of the study area and seismic pattern (very scarce), have led to the conclusion that the location of onshore mud volcanoes in the Upper Benue Trough, being located along the fault zones, is structurally controlled. The close relationship between mud volcano location and the structural framework of the area may be interpreted as one of several possible subsurface geological responses to present tectonic activity.
\end{abstract}

Key words: mud volcano, fault, tectonic stress, Kaltungo, Benue Trough

\section{Introduction}

For decades Nigeria has mainly been known for oil and gas resources accumulated in the south within the Niger Delta. Intensive exploration and exploitation activities being undertaken onshore, as well as offshore, led to the discovery of numerous circular features located on the upper continental slope of Gulf of Guinea, which are interpreted to be mud volcanoes 
(Graue 2000; Heggland et al. 2001). Investigations using geophysical techniques revealed that they can be active or dormant, are usually $1-2 \mathrm{~km}$ in diameter and have formed along seabed fault lines (Graue 2000; Heggland et al. 2001).

Mud volcanoes found on dry land in Nigeria were first reported a few years ago. The preliminary description of the mud volcanoes in Upper Benue Trough was presented by Musa et al. (2014), but the detailed geological and, in particular, the structural setting of the area of their occurrence are only now being presented in this paper. These onshore mud volcanoes are all located in the Upper Benue Trough, to the south of the Kaltungo inlier (Fig. 1). The majority are small, their cones usually do not exceed $2 \mathrm{~m}$ in diameter and $1.5 \mathrm{~m}$ in height.
They extrude intermittently either mud slurry or mineralized water that migrates to the surface from an unknown depth (Musa et al. 2014). The process controlling the formation of the Nigerian onshore mud volcanoes has yet to be satisfactorily clarified.

The Benue Trough is a NE - SW trending tectonic megastructure, described by many authors as a rift filled with a thick succession (up to $6 \mathrm{~km}$ ) of Cretaceous to Cenozoic sedimentary rock formations (Fitton 1980; Genik 1992; Zaborski 1998). Thick sedimentary succession comprising clayey beds is the basic condition for the creation of mud volcanoes, but there are other aspects and mechanisms facilitating the intrusion or extrusion of liquefied sediments.

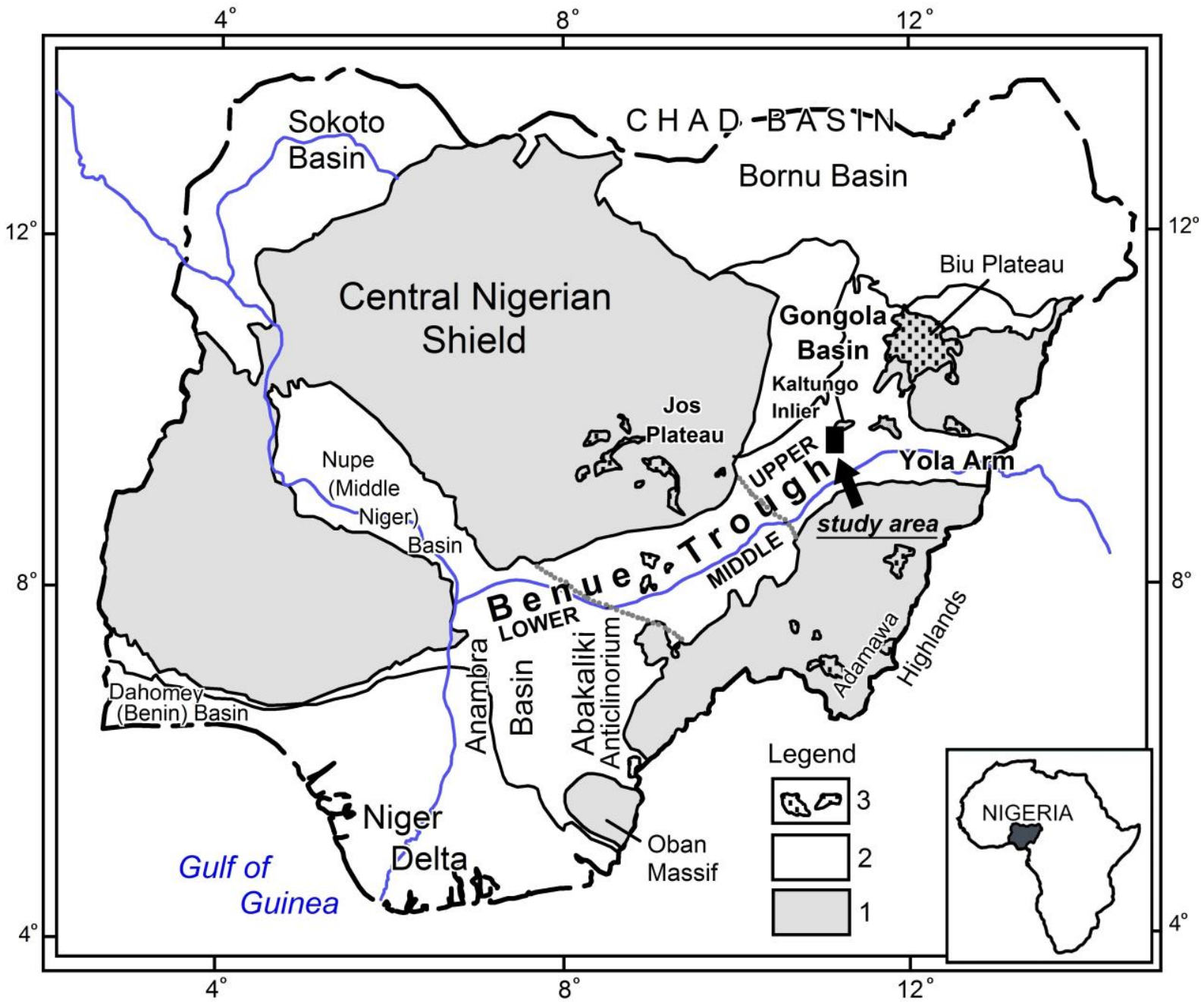

Fig.1. Location map of the study area on the background of general geological division of Nigeria: 1 - Precambrian basement, crystalline rocks, 2 - sedimentary basins (Cretaceous to Quaternary), 3 - Cenozoic volcanics. 
According to Kopf (2002) there are several conditions and causes of mud migration through rock mass: the occurrence of thick, rapidly deposited sequences of marine clays, density contrasts and density inversion in the deposits, and sediment overpressuring. These features and processes are usually accompanied by gas, brines, gas hydrate, water or oil emissions, hydrocarbon formation, diagenetic and metamorphic processes, tectonic shortening, and earthquakes or tectonic processes. Tectonic movements can remove sediments from their initial position and cause changes in the overburden stress field. Globally, mud volcanoes have been documented to occur within zones along the active boundaries of lithospheric plates, e.g in the Aleutians on the boundary between the Pacific and North American plates, or in Costa Rica on the boundary between the Cocos and North American plates (Kopf 2002). On passive margins mud volcanoes were documented on huge deltaic systems, e.g. on the northern slope of the Nile Deep Sea Fan (Dupré et al. 2008), and in hydrocarbon-rich areas within sedimentary basins, such as in the Caspian Sea region (Planke et al. 2003; Davies and Stewart 2005).

As is commonly observed in other global occurrences of onshore mud volcanoes, the Nigerian onshore mud volcanoes formed in an area of rapid sedimentation rates and intensive Cretaceous to Quaternary tectonism. This paper focuses on the geological setting and physical features of the Nigerian onshore mud volcanoes, two factors that are important in forming coherent conclusions on their origin.

\section{Materials and Methods}

The methods used in this study include fieldwork, which focused on the geological mapping and the recording of the locations of mud volcanoes, the interpretation of aerial photographs, and analysis of satellite images. All these activities resulted in the preparation of a map documenting the location of the onshore mud volcanoes (Fig. 2). Aerial photographs (scale 1:40,000) taken in 1964, covering the study area (Kaltungo surroundings), were obtained from the Nigerian Geological Survey Agency, Kaduna. Geological structures and lithological boundaries were deduced from both aerial photographs and high resolution satellite images provided by Google Earth. Field mapping was carried out over a period of three years (from 2012 to 2014), during which time data were obtained and annotated on 1:50,000 scale topographical maps: Sheet 173 Kaltungo NW and SW. Using GPS, the position of each mud volcano was taken and annotated on the topographical and geological maps. About 200 onshore mud volcanoes were documented and their distribution in relation to geological structures was examined during the fieldwork phase. Existing geological maps by Benkhelil et al. (1985), and Maurin and Robineau (1986) were also used. The dimensions of the mud volcanic cones were taken in the field using a measuring tape. Photographs of these cones were also taken. ArcGIS 9 software was used to prepare and produce an updated geological map using the acquired field data (Fig. 2).

\section{Structural Framework of Upper Benue Trough}

The Benue Trough extends from the Niger Delta in the south to the Chad Basin in the north (Fig. 1). It is bounded by NE - SW trending major faults believed to be of rift origins or an aulacogen, but upon which strike slip faults have been superimposed (Maurin et al. 1986). The subdivision of Benue Trough is based on different structural and stratigraphic features. The Upper Benue Trough comprises the $\mathrm{N}-\mathrm{S}$ trending Gongola arm and the $\mathrm{E}-\mathrm{W}$ trending Yola arm (Fig. 1). Between these two arms is a region representing the axial zone of the trough, which is structurally characterized by four major NE - SW trending sinistral strike-slip 


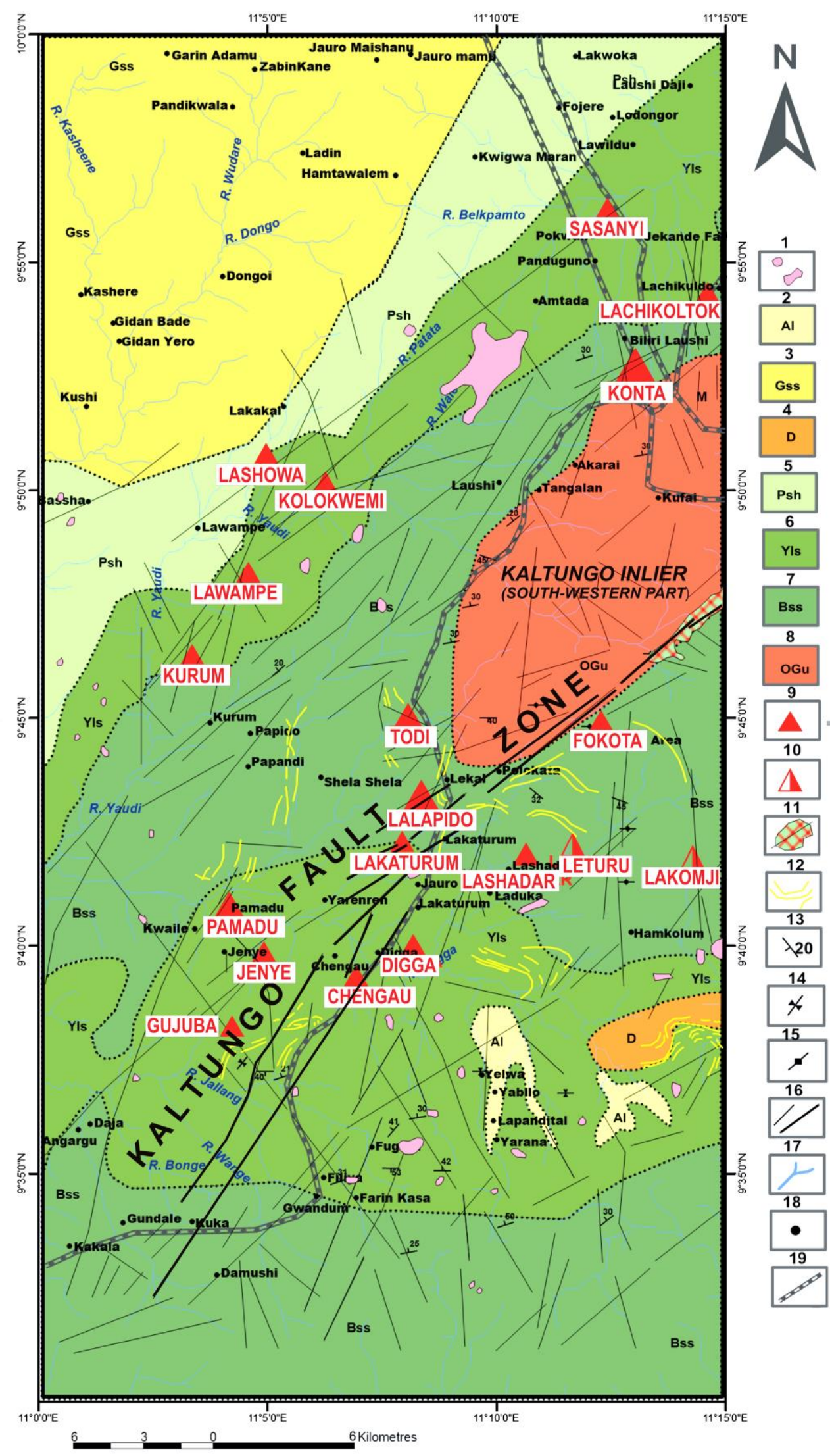


Fig.2. Geological map of the area and occurrence of mud volcanoes (modified after Benkhelil et al., 1985: the geological boundaries have been adjusted and mud volcanoes have been located on the map by the authors of this paper). Explanations: 1 - Neogenic volcanics, 2 - Alluvium, 3 - Gombe Sandstone (Maastrichtian), 4 - Dukul Formation (the lowest member of Pindiga Formation, Turonian), 5 - Pindiga Formation (Kanawa Member, Turonian - Santonian), 6 - Yolde Formation (Cenomanian), 7 - Upper Bima Sandstone (Albian), 8 - Precambrian basement (mainly granites) of Kaltungo inlier, 9 - mud volcanoes, 10 - warm springs, 11 - mylonite, cataclastite and fault breccia, 12 - traces of bedding 13 - dip and strike of beds, 14 - syncline, 15 - anticline, 16 - fault and fault zone; 17 - stream, 18 - settlements, 19 - road.

faults, namely, the Gombe, Bima-Teli, Kaltungo and Burashika faults (Benkhelil 1989; Zaborski et al. 1998). In addition to these faults, there are several basement inliers of which the Kaltungo inlier is the most prominent. The Gongola branch structural trend is controlled by a number of $\mathrm{N}-\mathrm{S}$ to NNE - SSW trending faults, while the Yola arm is characterized by deep embedded W - E trending fractures (Benkhelil 1988; Maurin, Guiraud 1989; 1990; Braide 1992; Zaborski et al. 1998). According to Maurin et al. (1986) and Benkhelil (1988), the major NE - SW shear zones developed on a pre-existing Pan-African mylonitic network.

\section{Stratigraphy and Lithology of the Study Area}

The stratigraphic succession of the Upper Benue Trough is described here as it occurs in each arm of the trough (for the Yola arm and for the Gongola arm). The synthesis of litostratigraphy of the area is presented in Tab.1,

Tab.1. Lithostratigraphic subdivision of the Gongola Basin as proposed by Zaborski et al. (1998), Popoff et al. (1986) and Carter et al. (1963); taken from Zaborski et al. (1998).

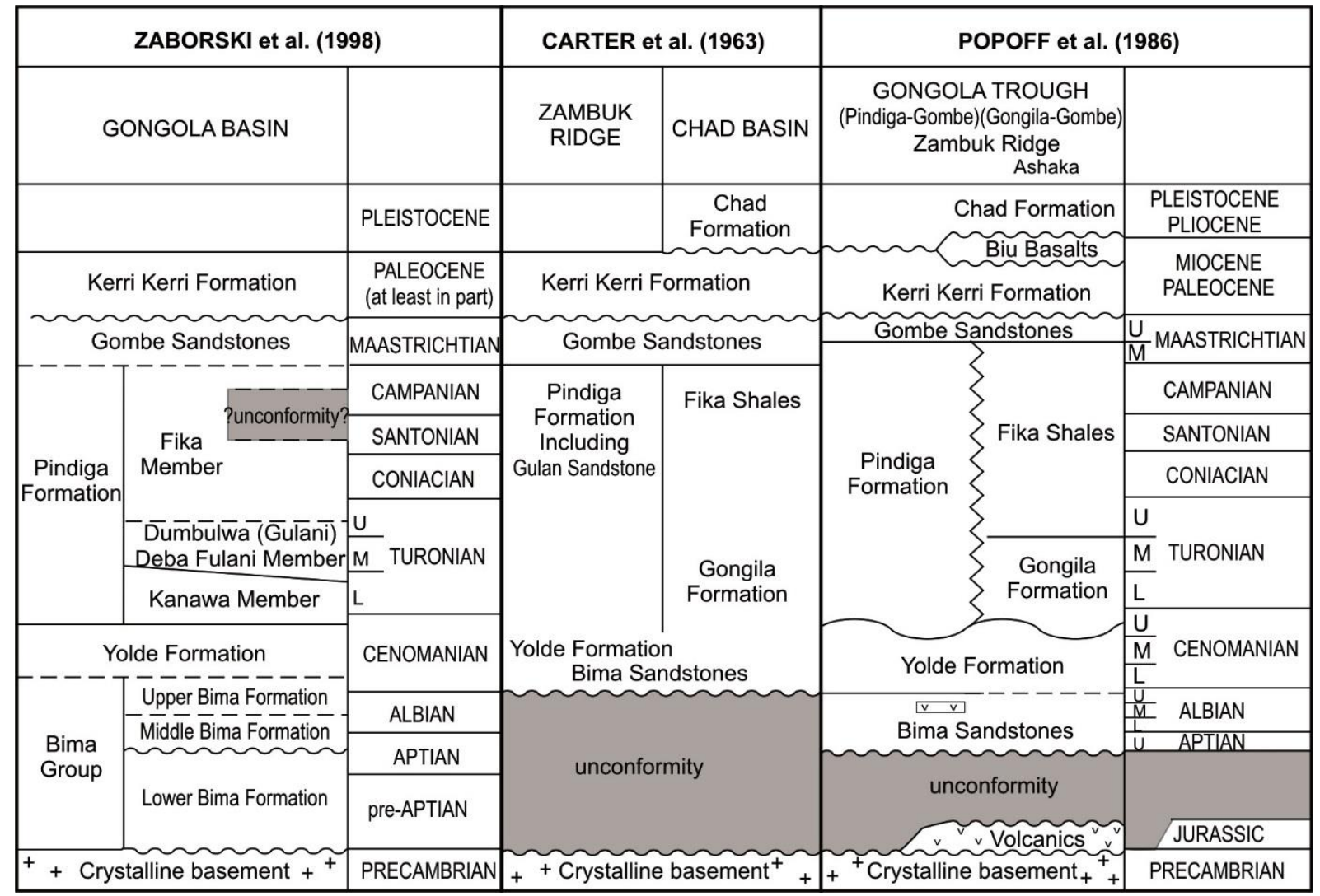


where the division for the Gongola arm is as documented by Carter et al. (1963), Popoff (1988) and Zaborski et al. (1998).

The geological map of the study area (Fig. 2) is dominated by a Late Cretaceous succession, comprising the Bima Sandstone (Late Albian), the Yolde Formation (Cenomanian), the Kanawa Member (Lower Turonian) of the Pindiga Formation, as well as associated volcanics (Neogene to Quaternary). The geological map produced for this study is similar to that of Benkhelil et al. (1985), Guiraud (1989) and Zaborski et al. (1998). The Upper Bima Formation covers the central, north-eastern and the southern portions of the study area. Towards the south of Todi, the Upper Bima Sandstone is characterized by tabular cross-bedded sandstone with sets 30 centimetres to one and half metres thick. The Yolde Formation outcrops in the central, southwestern, north-western and southern portions of the study area. This unit is generally characterised by gently undulating topography often with sparse vegetation. The Yolde beds consist of poorly consolidated, fine- to mediumgrained, moderately sorted, sub-rounded feldspathic sandstone. The Yolde Formation shows convolute bedding formed by tectonic activity on soft sediments deposited prior to lithification.

The Kanawa Member of the Pindiga Formation is restricted to the north-western portion of the study area. This unit usually forms flat topography, characterized by outcrops of dark clay with regoliths or blocks of fossiliferous limestone. Most often, the upper surfaces of the limestone show Thalassinoides burrows.

The youngest rocks in the area are represented by dark-coloured, fine-crystalline basaltic intrusions, of Neogene to Quaternary age, into the Bima Sandstone and the Yolde Formation. They usually form prominent hills in the mostly flat or slightly undulating study area (Zaborski et al. 1998).

\section{Structural Trends and their Relationship with Onshore Mud Volcanoes}

The predominant tectonic structures in the study area are a group of NE - SW trending faults, including the major Kaltungo Fault Zone. Minor faults trend $\mathrm{N}-\mathrm{S}$ and NW - SE (Figs. 2 and 3). At Lallapido and Lakaturu the fault that forms a section of the Kaltungo Fault Zone is marked by a zone of highly fractured and crushed rocks, $2 \mathrm{~m}$ in width; bedding dips gently NE, up to $30^{\circ}$ (Plates 1 and 2). These areas provide some of the best examples of the relationship between fault zones and mud volcano phenomena in the Upper Benue Trough. Both types of structure, i.e. mud volcanoes as well as faults, are distinct in the topography and easily observed in the field. Additionally, the tectonic lines are evident on the satellite images, further pointing to a relationship between the tectonic zone and distribution of the mud volcanoes. Figs. $4 \mathrm{a}$ and $4 \mathrm{~b}$ show the distribution of mud volcanoes in the area as seen in the satellite image and plotted on the geological map.

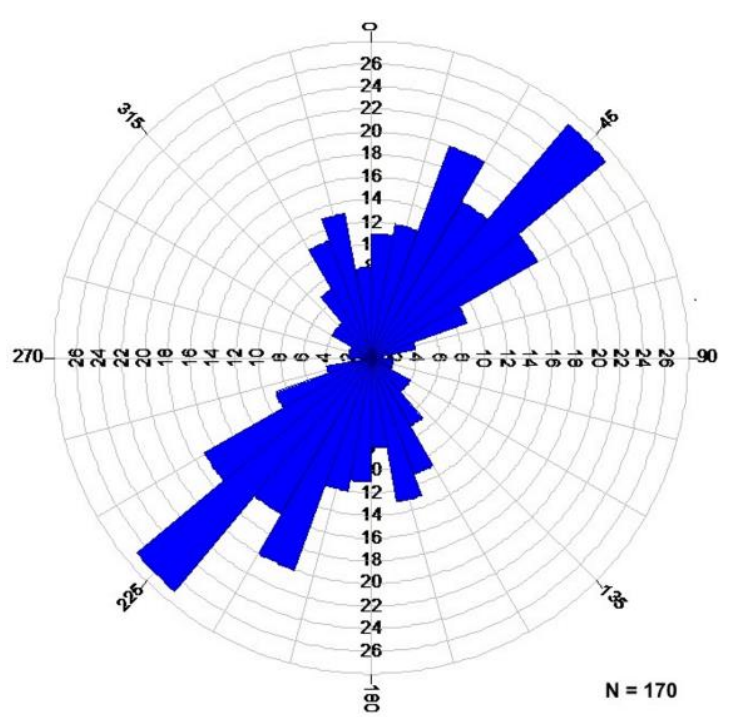

Fig.3. Rose diagram showing dominant NE - SW structural trend of faults in the study area. 
a)

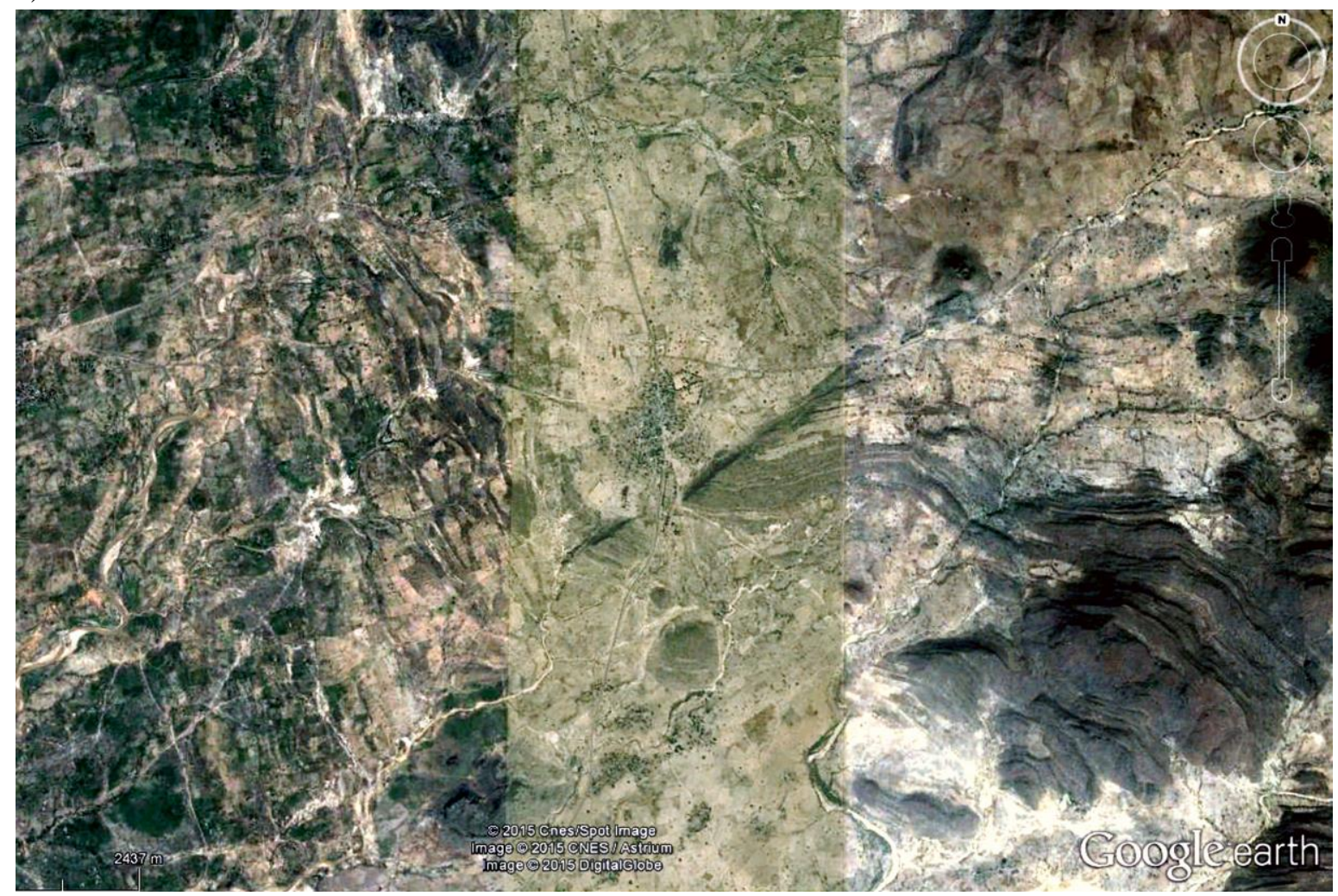

b)

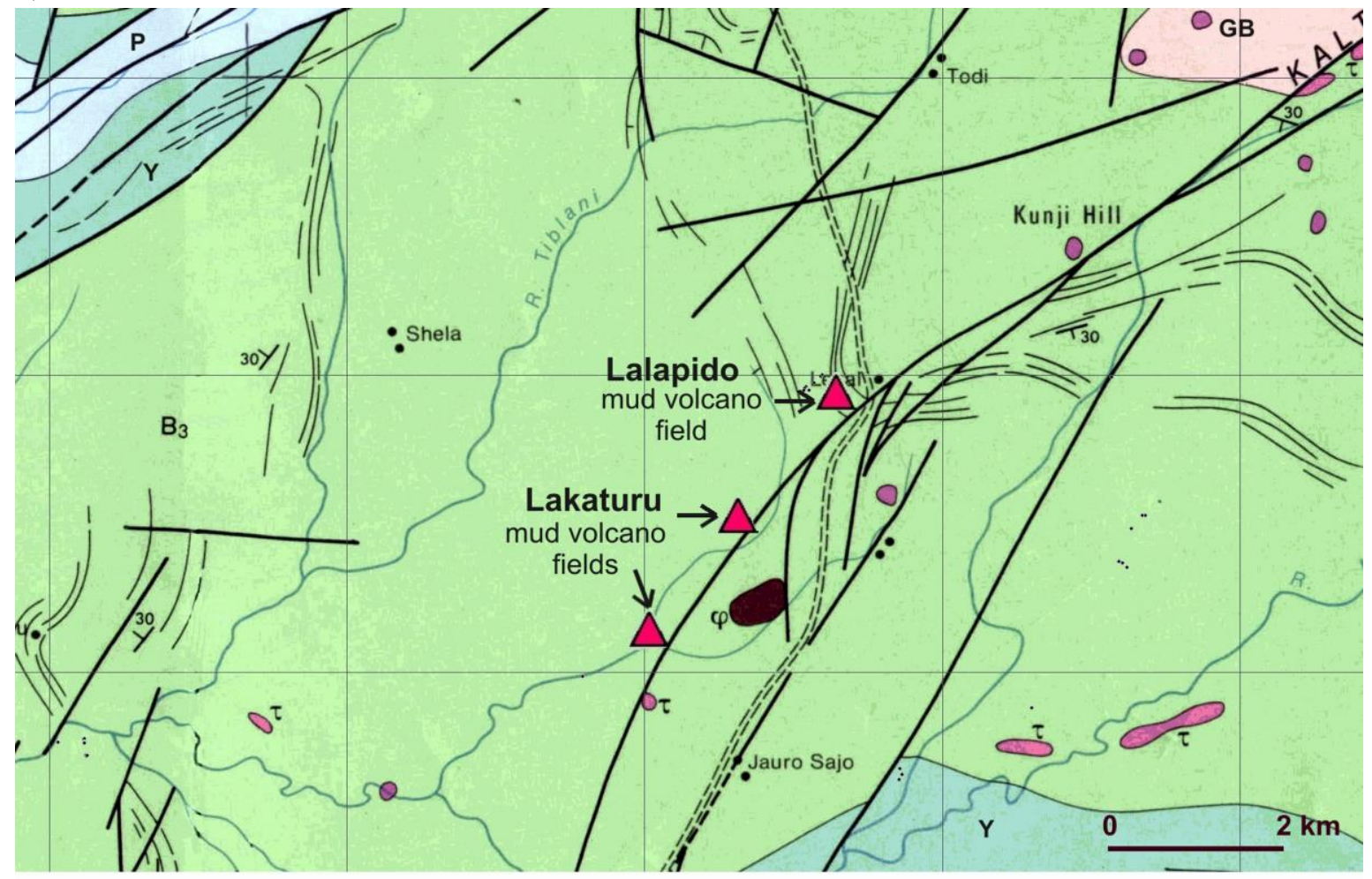

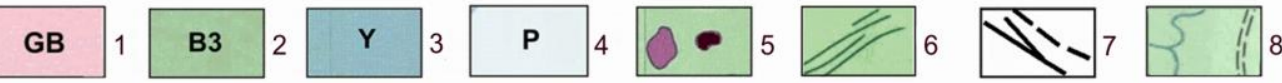


Fig.4. Structural setting of the south-western part of Kaltungo Fault Zone and surroundings and location of the mud volcanoes: a) satellite image: Google Earth (11/12/2013), area $20 \mathrm{~km} \mathrm{SW}$ from Kaltungo town, Nigeria, $9^{\circ}$

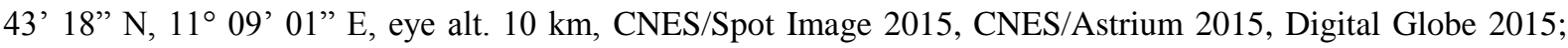
(accessed: $25^{\text {th }}$ October, 2015 http://www.earth.google.com); b) detailed geology of the same area as above, taken from Geological Map of Part of the Upper Benue Valley (scale 1:100,000) by Benkhelil et al. (1985), modified; explanations: 1. Upper Bima Sandstone (Albian), 2. Yolde Formation (Cenomanian), 3. Pindiga Formation, 4. Precambrian basement (mainly granites) of Kaltungo inlier, 5. Neogenic volcanics, 6. traces of bedding, 7. faults, 8. rivers and roads.

$\mathrm{N}-\mathrm{S}$ faults occur as minor faults within the study area, with only a few seen at Gujuba, Jenye and Pamadu within the Yolde Formation (Fig. 5). These faults occur alongside the major NE - SW Kaltungo lineament. At Gujuba, within the westernmost portion of the Dadiya syncline, one $\mathrm{N}-\mathrm{S}$ trending fault cuts across the Yolde and Upper Bima outcrops and, at the northern end, coexists with a small outcrop of basalt (Fig 5). Directly to the north of the syncline, on another $\mathrm{N}-\mathrm{S}$ trending fault, a prominent mud volcano field has developed (Gujuba occurrence). The syncline together with the faults cutting and which have shifted parts of the outcrop can be observed on the satellite image, and compared with the structural geology presented on the geological map (Figs. 5a and b). The Dadiya syncline is the major structural fold in the study area, having an axial trend of $\mathrm{NE}-\mathrm{SW}$, and beds on both limbs dipping at $40^{\circ}$. The Dadiya syncline is strongly asymmetric; both limbs are highly sheared, which suggests movement that is controlled by a deep-seated faults trending $\mathrm{N}-$ $\mathrm{S}$ and NW - SE, passing through the middle of the syncline (Figs. 5a and b).

NE - SW faults are noticeable mostly around the Chengau, Lashadar and Lakaturu areas (Fig. 2). The Todi mud volcano field, the first found in the Upper Benue Trough, belongs to the same set of mud volcanoes embedded in the NE - SW trending faults but is located in the peripheral part of the Kaltungo Fault Zone, northwest of its major line (Fig. 2).

\section{Characteristics and Proposed Origin of Onshore Mud Volcanoes in Nigeria}

Nigerian offshore mud volcanoes were previously reported in the Niger Delta (Graue 2000; Heggland et al., 2001) and were investigated using geophysical techniques. It was found that they are large structures, usually $1-2 \mathrm{~km}$ in diameter. Onshore mud volcanoes, however, have only been recently reported by Musa et al. (2014) even though the area was earlier subjected to hydrocarbon exploration (Thomas 1996; Abubakar et al, 2008). Onshore and offshore mud volcanoes found in Nigeria differ in terms of their size or number of volcanoes occurring in a particular field. While the offshore mud volcanoes on the Niger Delta continental slope appear massive and form individual occurrences, the onshore mud volcanoes in the Upper Benue Trough are much smaller, being not higher than $1.5 \mathrm{~m}$ and maximally $2 \mathrm{~m}$ in diameter. They occur in groups of 5 to 30 mud volcanic cones. Such groups have been termed "mud volcano fields" (Musa et al. 2014). The onshore mud volcanoes found in parts of the Upper Benue Trough do not contain oil or gases but fresh or, in most cases, highly mineralised water (Musa et al. 2015) (Plates 3 to 9). In other countries such as India (Chaudhuri et al. 2012; http://mudvolcanoes.weebly.com/baratang-island-mudvolcano-india.html), Venezuela (Aslan et al. 2001; Duerto, McClay 2002), Trinidad and Tobago (Knight et al. 2002), Mongolia (Rukavičková,

Hanžl 2008) 
a)

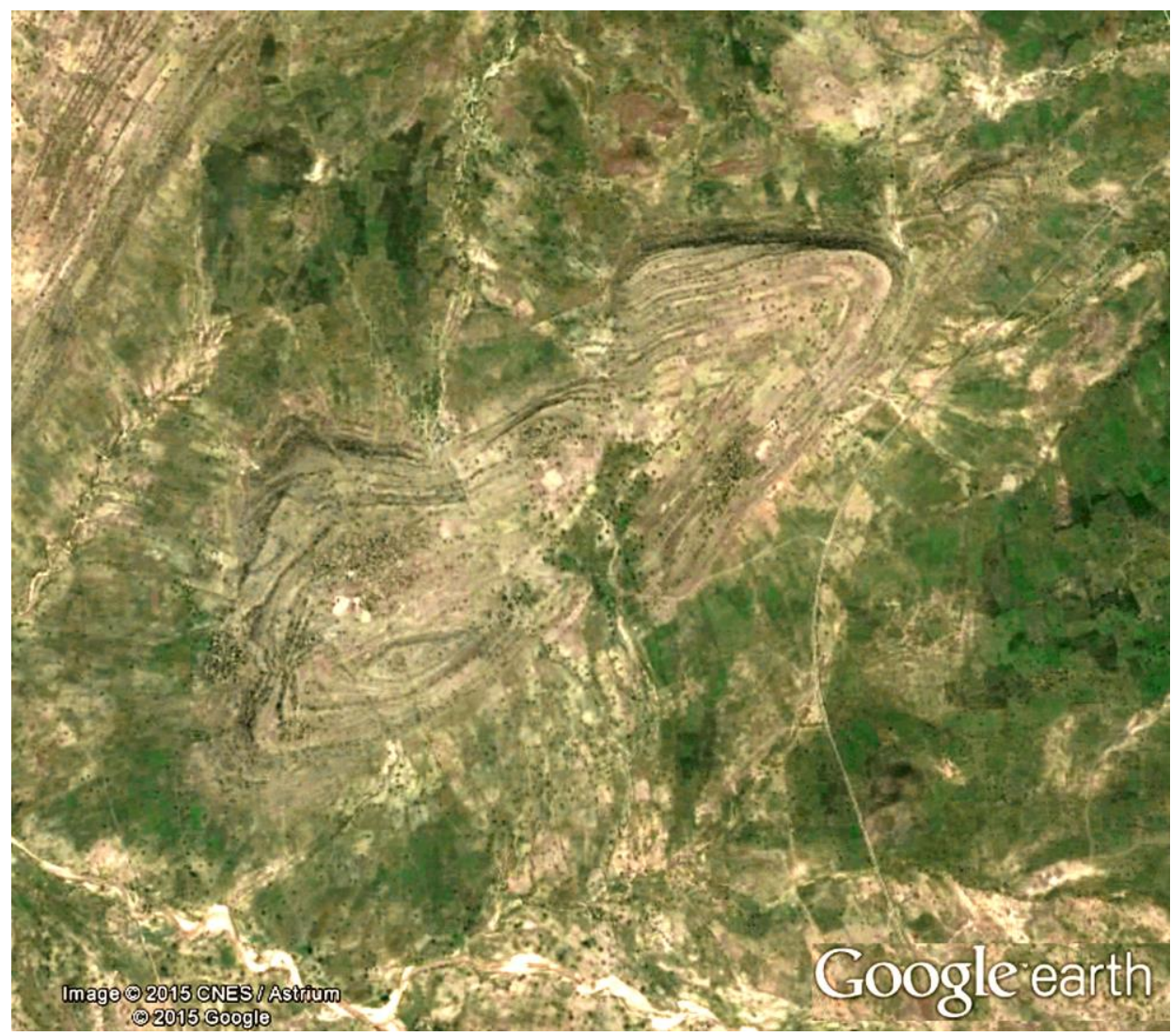

b)

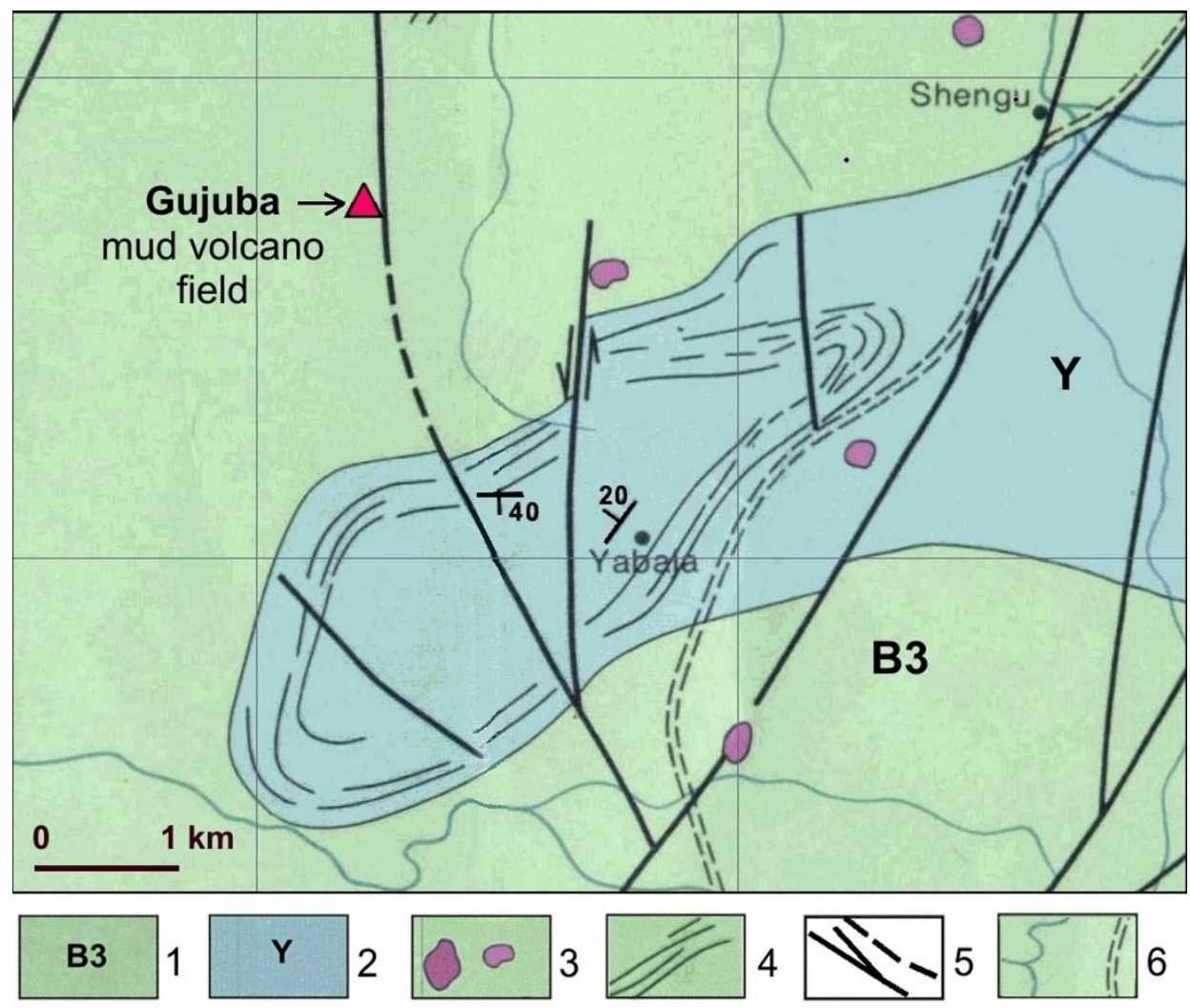


Fig.5: The westernmost part of Dadiya syncline cut by N - S, NW - SE and NE - SW trending faults. Some of the faults are associated with remains of basaltic and trachytic volcanoes (extinct now); the other one, north of the syncline, is associated with the mud volcano field of Gujuba (marked with red triangle): a) satellite image: Google Earth (11/12/2013), Dadiya syncline-western portion, Nigeria, 9० 38'02.51” N, $11^{\circ} 04$ ' 48.78” E, eye alt. 4.41 $\mathrm{km}, \mathrm{CNES} /$ Astrium 2015, (accessed: $25^{\text {th }}$ October, 2015http://www.earth.google.com); b) detailed geology of the Dadiya syncline and environs taken from Geological Map of Part of the Upper Benue Valley (scale 1:100,000) by Benkhelil et al. (1985), slightly modified; explanations: 1. Upper Bima Sandstone (Albian), 2. Yolde Formation (Cenomanian), 3. Neogenic volcanics, 4. traces of bedding, 5. faults, 6. rivers and roads.

and USA (California), (Rudolph, Manga 2010) there are onshore mud volcanoes substantially similar to those discovered in Nigeria in terms of their height, shape, size and mud flow from the crater. The scientific discussion regarding the origin of mud volcanoes is concerned mainly with the following categories: (a) mud volcanoes sensu stricto, linked with hydrocarbon gas release, (b) hydrothermal mud volcanoes, (c) mud volcanoes as a manifestation of an earthquake or a sudden exogenetic event (Pitt and Hutchinson 1982; Dimitrov 2002; Rogozhin et al. 2007 fide: Rukavičková, Hanžl 2008). The Nigerian onshore mud volcanoes, based on their sizes, heights, and geological nature, indicate they originated as a result of an earthquake or sudden exogenetic events as proposed by Rukavičková and Hanžl (2008). The authors observed that the argillaceous material ejected to the ground surface is derived from shallow depths. The height of this type of mud volcano usually reaches several decimetres, occasionally above one meter, whereas their diameter may attain several metres. Rukavičková and Hanžl (2008) concluded that rock-mass dislocation caused by an earthquake may be a factor that triggers fluid migration but there are other natural processes to consider: exogenetic events such as floods or landslides causing rapid strain increase in rocks, or sudden changes in piezometric pressure in aquifers, which result in the ejection of diluted sandy-clayey material to the ground surface. The description of the physical features of the mud volcanoes found in NW Gobi and Altay (Mongolia), which formed as a result of earthquakes and other exogenetic phenomena,
(Rukavičková and Hanžl 2008 and Rogozhin et al. 2007), is similar to the mud volcanoes found in the Upper Benue Trough of Nigeria.

The origin of the mud volcanoes in NW Gobi and Altay is closely associated with the recent seismic activity in the area (Rogozhin et al. 2007). In Nigeria, until recently, there was no monitoring system of seismic activity. In 2006 the Centre for Geodesy and Geodynamics in Toro initiated the development of the Nigerian National Network of Seismological Stations incorporating the first six seismic stations in Nigeria (Afegbua et al. 2011). Hitherto, however, there were no available professional records of seismic activity in the study area.

Despite the fact that Nigeria has been perceived as aseismic region, there are some historical records documenting cases of seismic activity in several locations in the recent decades (Ajakaiye et al. 1988; Osagie 2008). The most frequent earthquakes were observed in the SW of Nigeria, near Warri, Lagos, Ibadan and Akure. There are also records of earthquakes in the Upper Benue Trough, near Gombe (in Komba Yaya in 1985 and Akko in 1987), as well as Yola (in 1984 and 2005), (Ajakaiye et al. 1988; Akpan, Yakubu 2010; Tsalha et al. 2015). No earthquakes have been reported close to the vicinity of Kaltungo. However, the quake sites near Gombe are located within a distance of about 30 to $50 \mathrm{~km}$ from the study area. Interestingly, Gombe, together with Bima-Teli, Burashika, and Kaltungo fault zones and inliers form part of the same network of strike-slip faults cutting the Upper Benue Trough into a system of uplifted 
blocks and basins (Maurin et al. 1986 and Benkhelil 1988). These authors suggest the movement of the blocks along transcurrent fault planes during the structural development of the Benue Trough over a period spanning the Aptian to Palaeocene. During this period, due to syntectonic deposition, the sedimentary basins, together with the basin bounding and intersecting crushed fault zones, were irregularly filled with fine-grained sediments, which constitute a source material for the contemporary mud volcano phenomena. If we assume that the tectonic compressional or shear stress in the area has not ceased, as is evident from the earthquakes that have been observed for the past few decades in the region, it can be deduced that the tectonic factors may trigger the movement of the overpressured, poorly consolidated sediments saturated with water, pushing them up to the surface, possibly throughout the fault zones to form the mud volcanoes. This hypothesis has yet to be proven, as there are no professional seismic data available to verify this proposal. However, the earthquakes near Gombe and Yola support the assertion that the Upper Benue Trough is not an aseismic area. The occurrence of mud volcanoes along the fault lines in the study area may therefore be interpreted as an effect of present-day tectonic stress squeezing the finegrained sediments deposited in the active tectonic zones.

\section{Conclusions}

Evaluation of the tectonic setting and the distribution of onshore mud volcanoes found in the Upper Benue Trough indicate a relationship between major Kaltungo faults and the mud volcanoes in Fokota, Lalapido, Lakaturu, Digga, Chengau, Jenye, Pamadu and Gujuba. The mud volcanoes are located mainly at the south-western end of the NE - SW trending Kaltungo Fault Zone. The remaining mud volcano fields are located on other, minor, $\mathrm{N}-$ $\mathrm{S}$ and NW - SE trending faults in the area.
Therefore the authors of the paper propose that the mud volcanoes are structurally controlled, occurring in groups of 5 - 30 volcanoes, known as "mud volcano fields" in and around areas that have undergone tectonic activity.

It is currently accepted that the structural evolution of the Upper Benue Trough ended in the Palaeocene, although episodes of tectonic activity (earthquakes) have been observed in that area over the last 35 years. It is possible that the earthquakes near Gombe and Yola were manifestations of ongoing but diminishing tectonic activity. Although declining, ongoing tectonic activity in the Upper Benue Trough may be a causal factor in the extrusion of mud and fluids from fault zones to the ground surface leading to the formation of mud volcano cones. However, further research on relationship between the development of the mud volcanoes and seismicity of the area is needed. The depth of the source material seeping from mud volcanoes is not known and should be examined along with a full study of the mechanisms controlling mud and fluid migration through the subsurface fissure system.

\section{References}

Abubakar M. B., Dike E. F. C., Obaje N. G., Wehner H., Jauro A. (2008) Petroleum prospectivity of Cretaceous Formations in the Gongola Basin, Upper Benue Trough, Nigeria: an organic geochemical perspective on a migrated oil controversy. Journal of Petroleum Geology. 31(4), 387408.

Ajakaiye D. E., Olatinwo M. D., Scheidegger A.E. (1988) Another Possible Earthquake Near Gombe in Nigeria on the 18-19 June 1985. Bulletin of the Seismological Society of America. 78, 2, 1006-1010.

Akpan O. U., Yakubu T. A. (2010) A review of earthquake occurrences and observations in Nigeria. Earthquake Science. 23, 3, 289294. 
Aslan A., Warne A. G., White W. A., Guevara E. H., Smyth R. C., Raney J. A., Gibeaut J. C. (2001). Mud volcanoes of the Orinoco Delta, Eastern Venezuela. Geomorphology. 41, 323-336.

Benkhelil J. (1988) Structure et évolution géodynamique du basin intracontinental de la Bénoué Nigeria). Bulletin Centres Recherches exploration-Production ElfAquitaine. 12, 29-128.

Benkhelil J. (1989) The origin and evolution of the Cretaceous Benue Trough, Nigeria. Journal of African Earth Science. 8, 251 282.

Benkhelil J., Maurin J. C., Robineau B. (1985) Geological Map of Part of the Upper Benue Valley (scale 1:100000) (with explanatory note). Elf Nigeria Ltd., Lagos. Nigeria.

Braide S. (1992) Tectonic origin of preconsolidation deformation, Bima Sandstone, Yola Basin, Benue Trough. Bulletin Nigerian Association Petroleum Explorationists. 7, 39-45.

Carter J. D., Barber W., Tait E. A., Jones G. P. (1963) The Geology of Parts of Adamawa, Bauchi and Borno Provinces in Northeastern Nigeria. Bulletin of the Geological Survey of Nigeria. 30, 1- 108.

Davies R. J., Stewart S. A. (2005) Emplacement of giant mud volcanoes in the South Caspian Basin: 3D seismic reflection imaging of their root zones. Journal of the Geological Society. 162, 1, 1-4.

Dimitrov L. I. (2002) Mud volcanoes - the most important pathway for degassing deeply buried sediments. Earth-Science Reviews. 59, 49-76.

Duerto L., McClay K. (2002) 3D geometry and evolution of shale diapirs in the Eastern Venezuelan Basin. Royal Holloway University of London and PDVSA Petroleos de Venezuela, Fault Dynamics Research Group. (Website: accessed $2^{\text {nd }}$ March, 2016 http://www.searchand discovery.com/documents/duerto/images/p ost1.pdf)
Dupré S., Buffet G., Mascle J., Foucher J.-P., Gauger S., Boetius A., Marfia C., The AsterX AUV Team, The Quest ROV Team, The BIONIL scientific party (2008) Highresolution mapping of large gas emitting mud volcanoes on the Egyptian continental margin (Nile Deep Sea Fan) by AUV surveys. Marine Geophysical Researches. 29, 275-290.

Fitton J.G. (1980) The Benue Trough and Cameroon Line - a Migrating Rift System in West Africa. Earth and Planetary Science Letters. 51, 132-138.

Guiraud M. (1989) Geological map of part of the Upper Benue Valley (scale 1:150000) (with explanatory note). Elf Nigeria Ltd, Lagos, Nigeria.

Genik G.J. (1992) Regional Framework, Structural and Petroleum Aspects of Rift Basins in Niger, Chad and The Central African Republic (C.A.R.). Tectonophysics. 213, 169-185.

Graue K. (2000) Mud volcanoes in deep water Nigeria. Marine and Petroleum Geology 17, 959-974.

Heggland R., Nygaard E., Gallagher J. W. (2001) Techniques and experiences using exploration 3D seismic data to map drilling hazards, Offshore Technology Conference, OTC 7968, 119-127.

Knight J. C., Scott J. P., Grierson L. H. (2002) The Devil's Woodyard Mud Volcano of Trinidad: Chemistry and Mineralogy. [In:] Caribbean Geology into the Third Millennium (ed. T. A. Jackson). University of West Indies Press. Barbados-JamaicaTrinidad and Tobago.

Maurin J. C., Benkhelil J., Robineau B. (1986) Fault rocks of the Kaltungo lineament, NE Nigeria, and their relationship with Benue Trough tectonics. Journal of the Geological Society, London. 143, 587-599.

Maurin J. C., Guiraud M. (1989) Relations entre tectonique et sédimentation dans les basins barrémo-aptiens du Nord Cameroun. 
Comptes Rendus Académie Sciences Paris (II). 308, 787-792.

Maurin J. C., Guiraud R. (1990) Relationships between tectonics and sedimentations in the Barremo-Aptian intracontinental basins of northern Cameroon. Journal African Earth Sciences. 10, 331-340.

Musa O. K., Kurowska E., Schoeneich K. Alagbe S. A. (2014) Mud volcanoes on the dry land of Nigeria. African Geoscience Review. 21, 1 \& 2, 15 - 23.

Musa O. K., Kurowska E. E. A., Schoeneich K., Alagbe S. A. (2015) Chemistry of groundwater from mud volcanoes in parts of Upper Benue Trough, northeastern Nigeria. Journal of Environmental Earth Sciences. 74, 4897-4906.

Osagie E. O. (2008) Seismic activity in Nigeria. The Pacific Journal of Science and Technology. 9, 2, 546 - 551.

Pitt, A. M., Hutchinson, R.A. (1982): Hydrothermal changes related to earthquake activity at Mud Volcano, Yellowstone National Park, Wyoming, J Geophys Res 87(B4): 2762-2766.

Planke S., Svensen H., Hovland M., Banks D. A., Jamtveit B. (2003) Mud and fluid migration in active mud volcanoes in Azerbaijan. Geo-Marine Letters. 23, 258268.

Popoff M. (1988) Du Gondwana à l'Atlantique sud: connexions du fossé de la Bénoué avec les bassins du Nord-Est brésilien jusqu'à l'ouverture du golfe de Guinée au crétacé inférieur. Journal of African Earth Sciences (and the Middle East). 7, 2, 409-431.

Popoff M., Wiedmann, J., de Klasz I. (1986) The Upper Cretaceous Gongila and Pindiga Formations, northern Nigeria. Subdivisions, age, stratigraphic correlations and paleogeographic implications. Eclogae Geologica Helv. 79, 2, $343-363$.
Rogozhin E. A., Ovsyuchenko A. N., Marakhov A.V., Ushanova E.A. (2007) Tectonic setting and geological manifestations of the 2003 Altai Earthquake. Geotectonics. 41, 87-104.

Rudolph M. L., Manga M. (2010) Mud volcano response to the 4 April 2010 El MayorCucapah earthquake. Journal of Geophysical Research. 115, B12211, 1-14.

Rukavičková L., Hanžl P. (2008) Mud volcanoes in the Khar Argalantyn Nuruu, NW Gobi Altay, Mongolia as manifestation of recent seismic activity. Journal of Geosciences. 53, $181-191$.

Thomas D. (1996) NIGERIA-5 Benue trough and the mid-African rift system. The Oil \& Gas Journal, 01/29/1996. (Website: accessed $2^{\text {nd }}$ March, 2016 http://www.ogj. com/articles/print/volume-94/issue-5/inthis -ssue/exploration/nigeria-5-benue-troughand-the-mid-african-rift-system.html).

Tsalha M. S., Lar, U. A., Yakubu, T. A, Kadiri, U. A., Duncan, D. (2015) The Review of the Historical and Recent Seismic Activity in Nigeria. IOSR Journal of Applied Geology and Geophysics (IOSR-JAGG). 3, 1, 48-56.

Zaborski P. M. (1998) A review of the Cretaceous System in Nigeria. Africa Geoscience Review. 5, 385 - 483.

Zaborski P., Ugodulunwa, F., Idornigie, A., Nnabo, P., Ibe, K. (1998) Stratigraphy and Structure of the Cretaceous Gongola Basin, northeast Nigeria. Bulletin de Centre des Recherches Exploration Production ElfAquitaine. 21, 153 - 186.

Websites:

http://www.earth.google.com (accessed: 25 ${ }^{\text {th }}$ October, 2015)

http://mud-volcanoes.weebly.com/baratangisland-mud-volcano-india.html (accessed $2^{\text {nd }}$ March, 2016). 


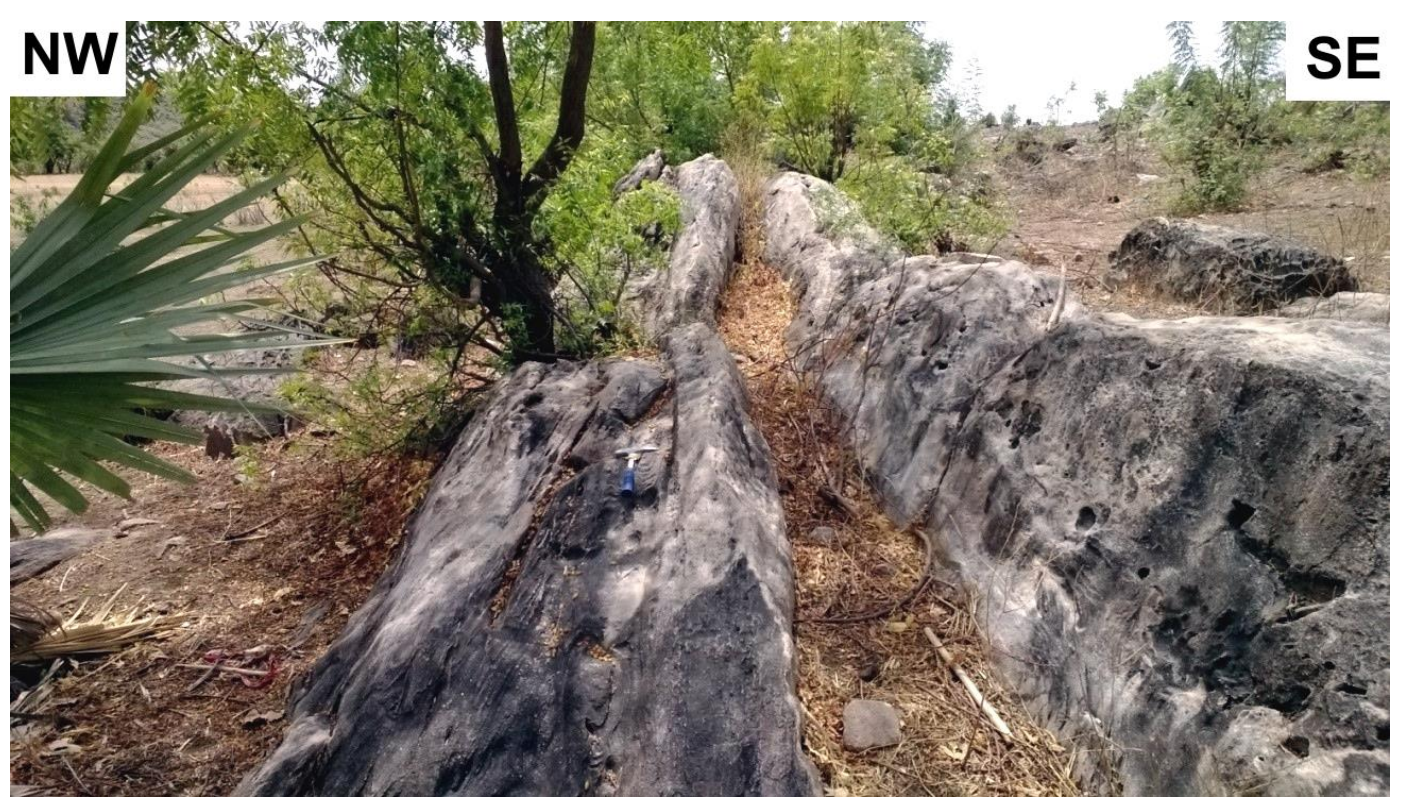

Plate 1. NE - SW trending fault being a part of the Kaltungo Fault Zone within the Upper Bima Formation at Lallapido (location of the site: $\mathrm{N} 09^{\circ} 43^{\prime} 13^{\prime \prime}$ and E01 $08^{\prime} 58^{\prime \prime}$ ).

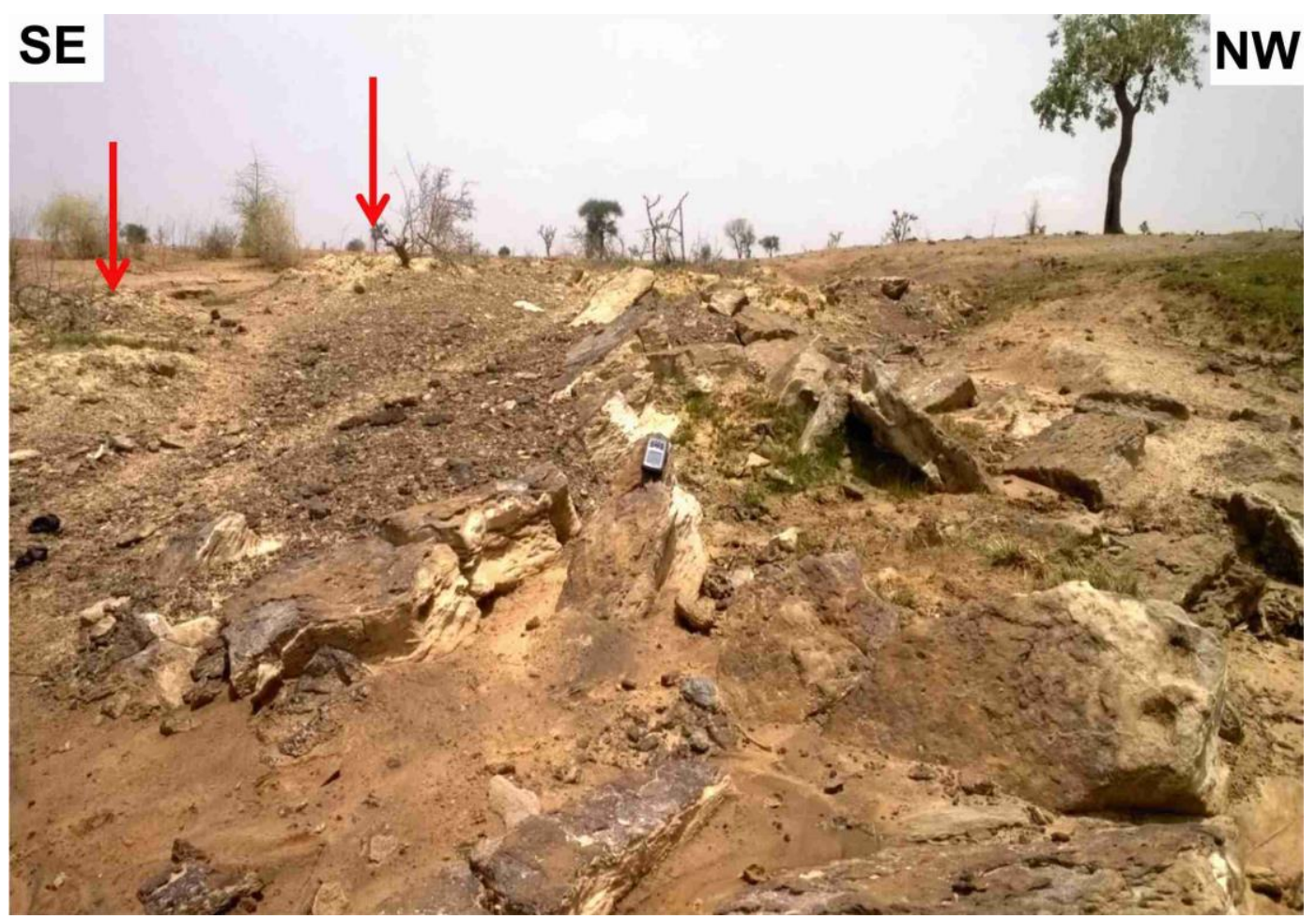

Plate 2. Faulted Yolde Formation at Lakaturu showing trend of NE - SW with mud volcanoes around it (pointed with red arrows) (location of the site: N9 $42^{\prime} 11.5^{\prime \prime}$ and E11 ${ }^{\circ} 07^{\prime} 42.1^{\prime \prime}$ ). 


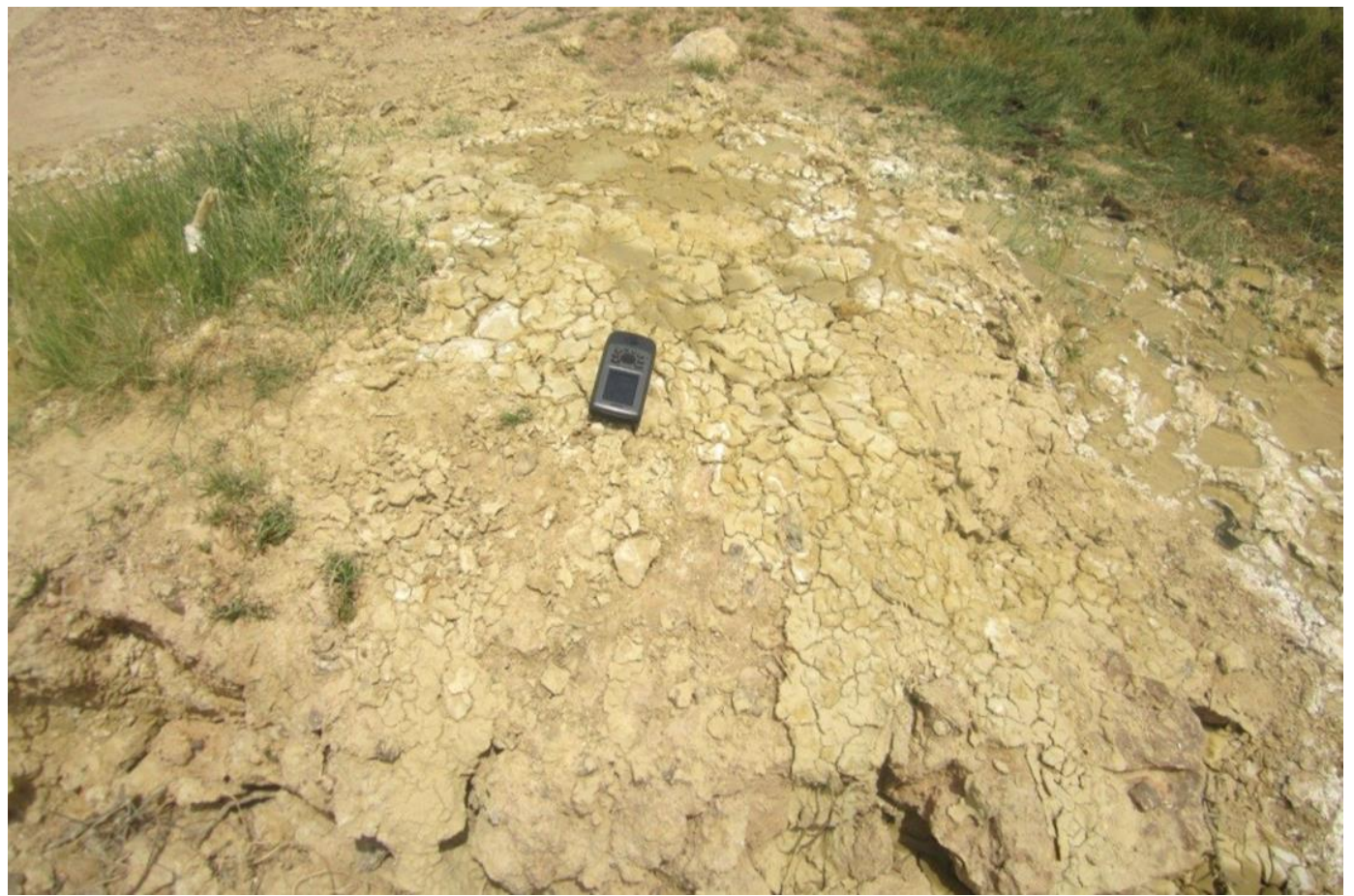

Plate 3. Mud volcano at Lakaturu, showing dry and fresh mud flowing from the crater. Photo taken facing north at N0942'11.9”' E01 $^{\circ} 07^{\prime} 44.8$ (source: Musa et al. 2014).

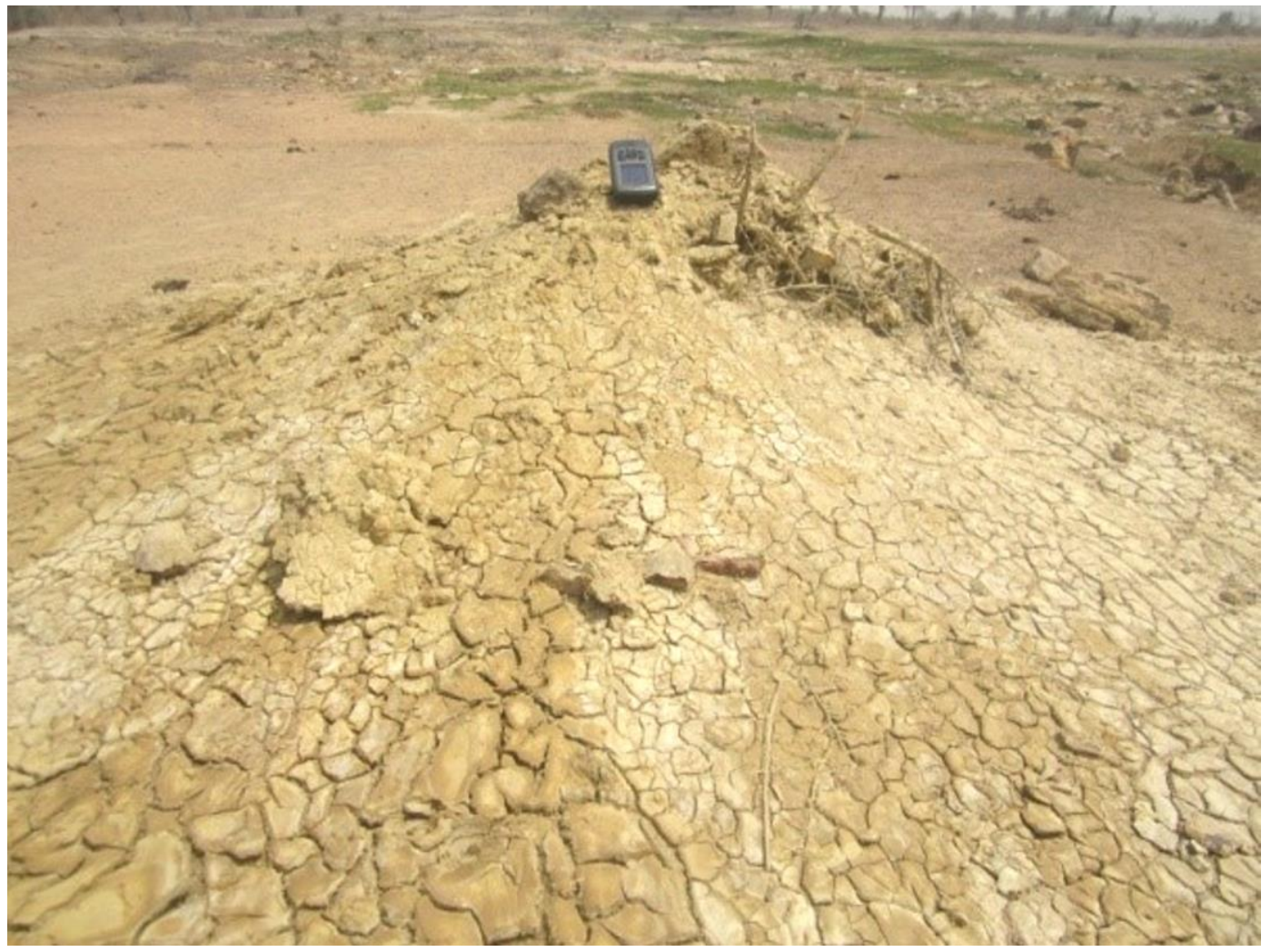

Plate 4. A mud volcano at Kurum village showing mineralization in form of white powder at slopes of the cone, dry mud and fresh mud flowing from the crater. Photo taken facing north - east at N09 46'15.1" E011 03 '04.4" (source: Musa et al. 2014). 


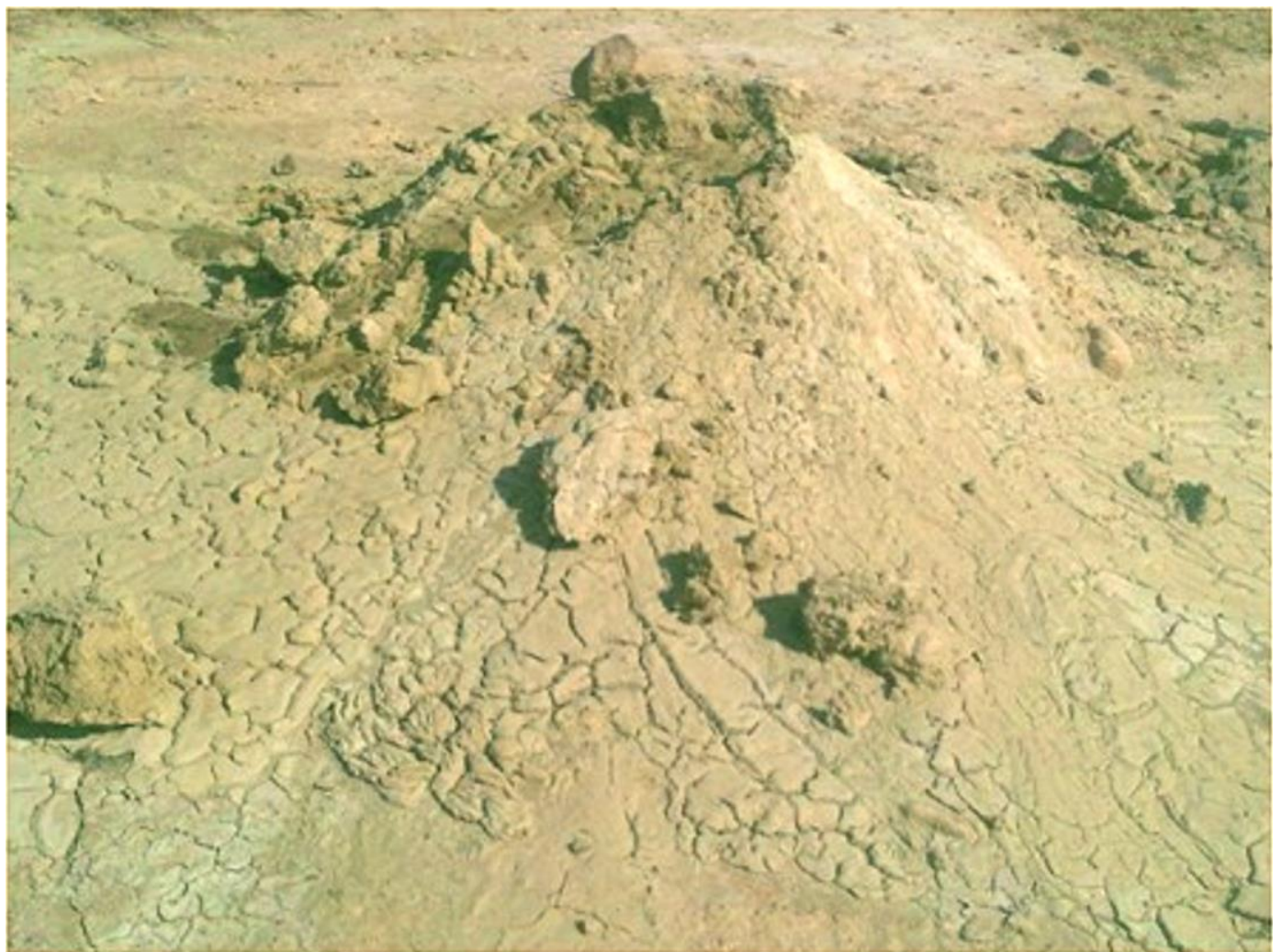

Plate 5. One of the mud volcanoes in Lallapido, showing dry mud and fresh mud flow. Photo taken facing north at $\mathrm{N}^{\circ} 9^{\circ} 43^{\prime} 11.4^{\prime \prime}$ and E011 $08^{\prime} 58.9^{\prime \prime}$ (source: Musa et al. 2014).

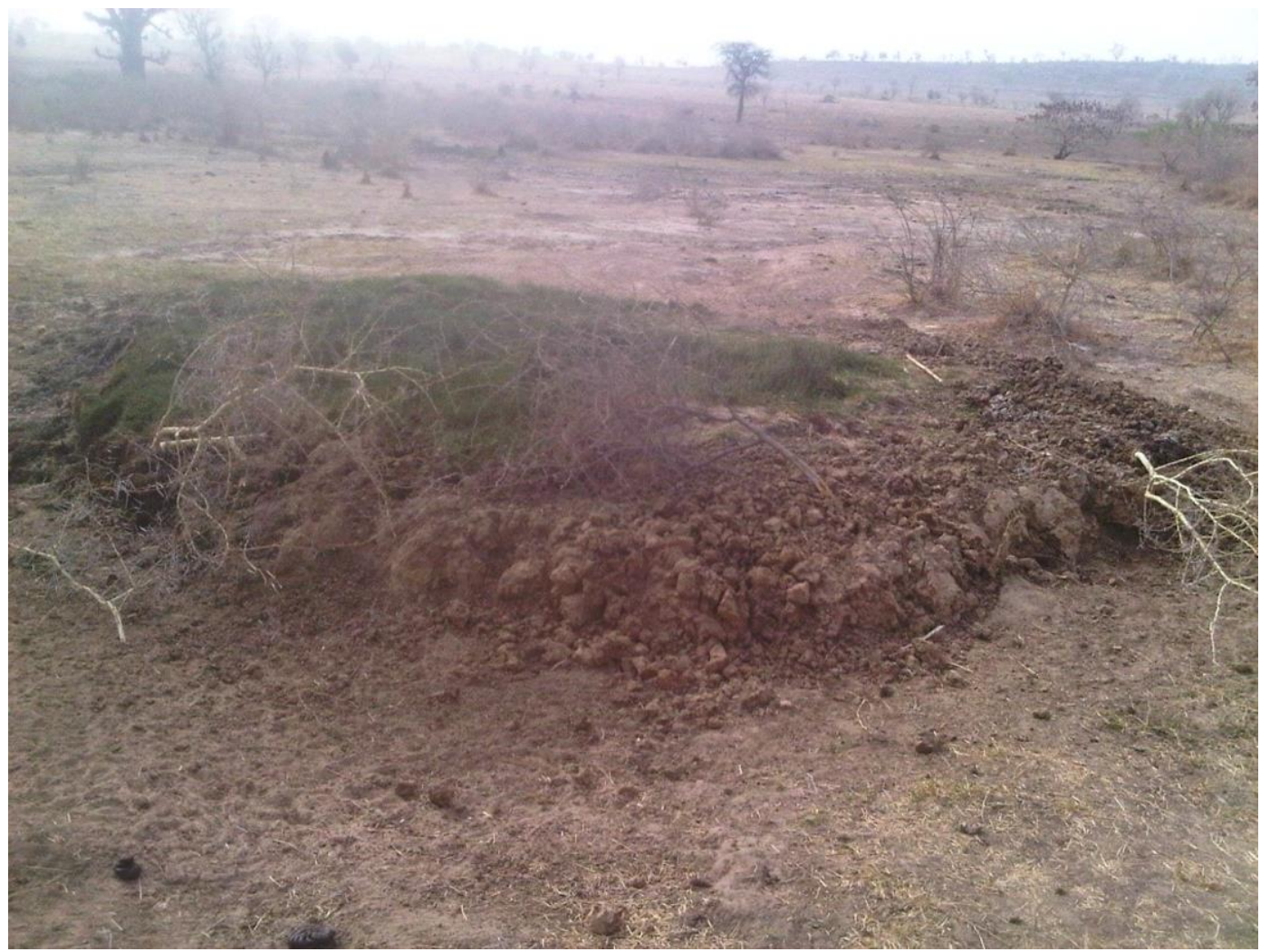

Plate 6. A mud volcano at Jenye with slurry of mud and water seeping from the crater with grass seen on top of the crater. Photo taken facing east at N09 $39^{\prime} 47.4^{\prime \prime} \mathrm{E} 011^{\circ}$ 4'39.6”. 


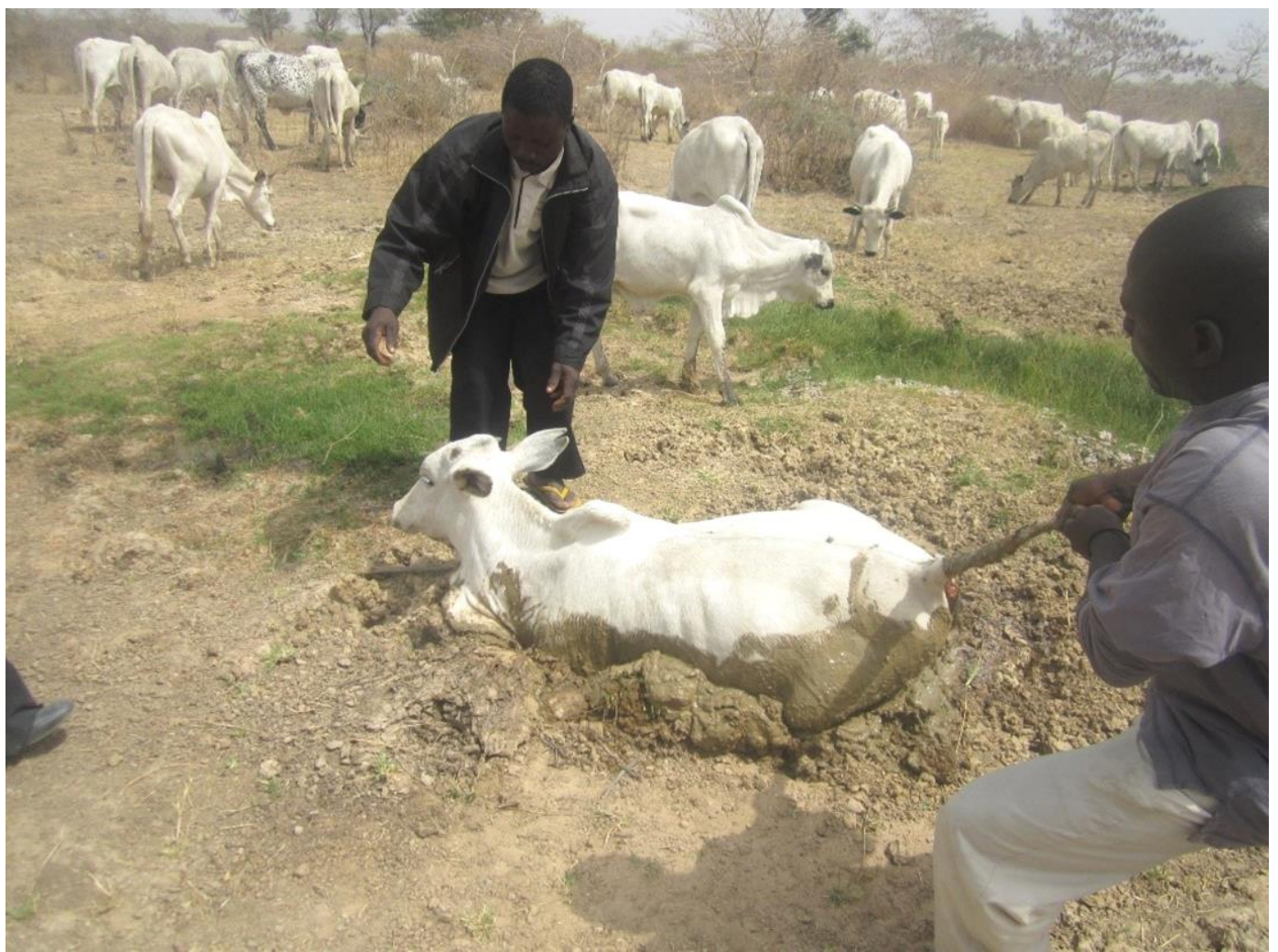

Plate 7. A cow being rescued from a mud volcano at Jenye, the cow came to the mud volcano to lick the salt. Photo taken facing east at N09 $39^{\prime} 46.2^{\prime \prime}$ and E011 $04^{\prime} 41.0^{\prime \prime}$ (source: Musa et al. 2014).

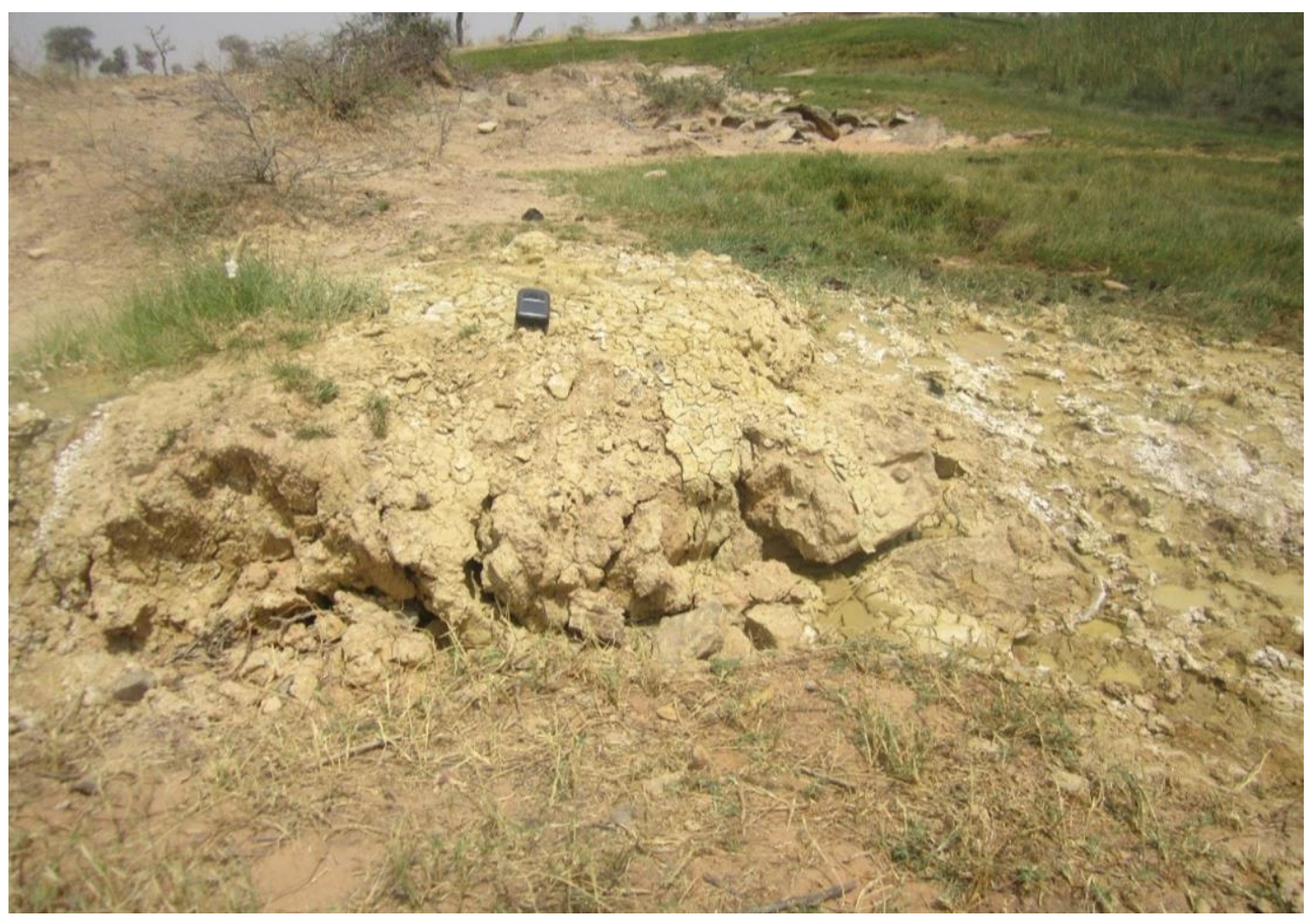

Plate 8. A mud volcano at Lakaturu with slurry of mud and water seeping from the crater with whitish precipitates seen around the crater. Photo taken facing north at N09 42 ' $12.1^{\prime \prime}$ E011 ${ }^{\circ} 07^{\prime} 42.5^{\prime \prime}$. 


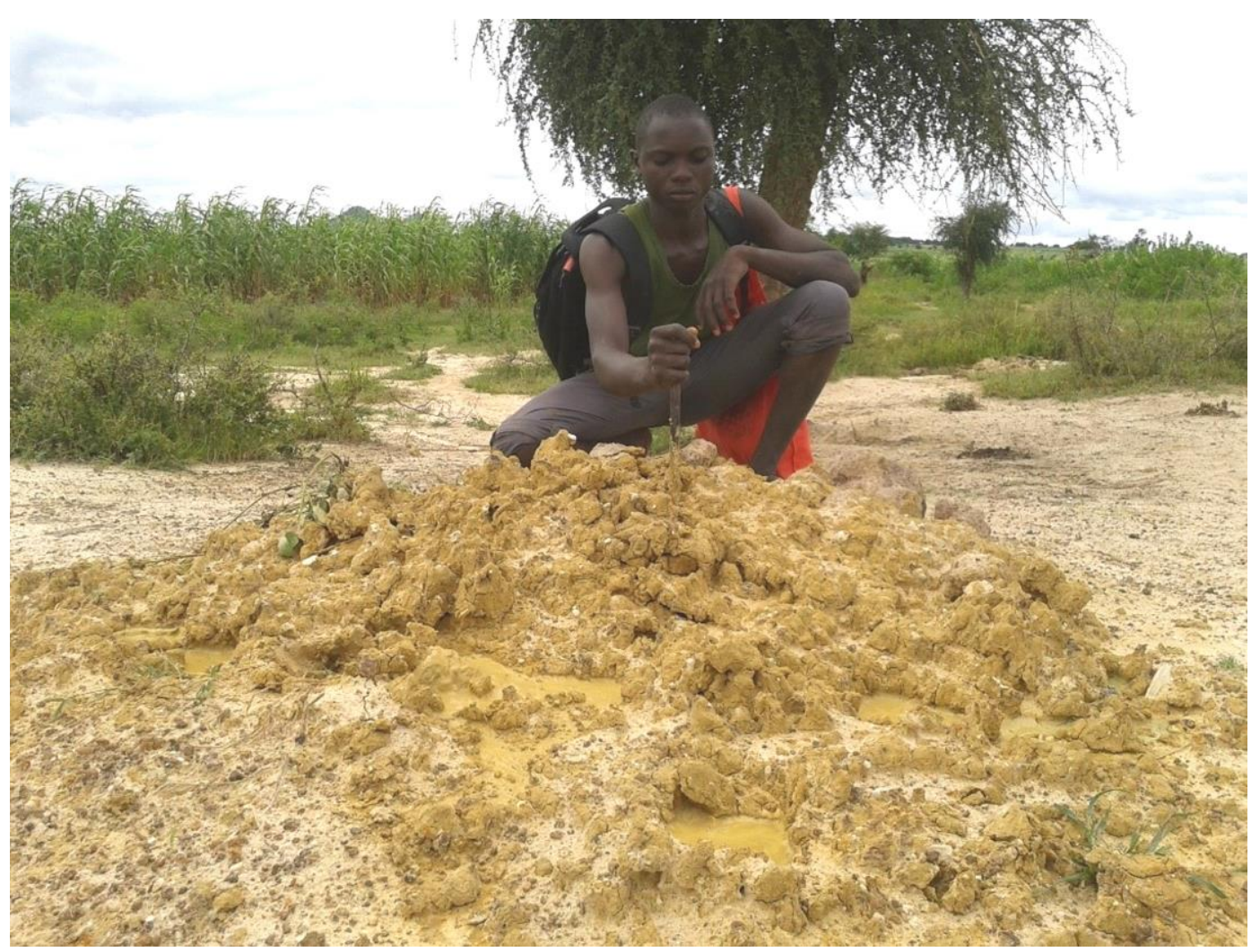

Plate 9. A mud volcano at Pamadu village showing mineralization, dry mud and fresh mud flowing from the

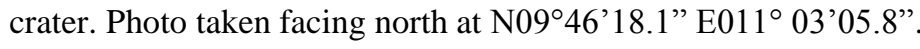

